BABELAO 5 (2016), p. 285-300

(C) ABELAO (Belgium)

\title{
Wedding songs in the dialect of the Jews of Habbān in eastern Yemen
}

By

\section{Aharon Geva-Kleinberger}

University of Haifa

$\mathrm{T}$

The village of Habbān was a village inhabited by one of the most amazing and most isolated Jewish communities in the world. Called Hábbon in its Jewish dialect, it is located in eastern Yemen in present-day Shabwa (Šabwa) district, some $300 \mathrm{~km}$ north-east of Aden and about $100 \mathrm{~km}$ from the Indian Ocean. This Jewish community numbered 450 people in 1947. Although the administrative Yemenite district belongs to Shabwa, the Jewish community of Habbān tends to regard its place of origin as the Hadramawt (Hadramawt) region. They attribute their small number to innumerable pogroms and riots that forced them to convert to Islam. Habbān was remote geographically from other Yemenite Jewish communities, with which it had hardly any contact. The Habbāni Jews were renowned as excellent goldsmiths and sil- 
ver and gold jewellers; their dialect contains an enormous vocabulary in this field. The history of the first settlement of Jews in this remote corner of the southern Arabian Peninsula is shrouded in mystery. Their outward appearance distinguishes them from other Jewish communities in Yemen: they had long hair, would go about half-naked, and wore no kippa on their heads. Local traditions date this community to the First Temple era. These Jews differed from their Yemenite co-religionists in their appearance and religious tradition, ${ }^{1}$ but also in their Jewish dialect with its very large original vocabulary, which may well have been preserved because of their isolation. Thus customs and folklore in this community are unique and preserve ancient and singular traditions. The Habbāni Jews (Sing.m Habbāni, Sing.f. Habbānyah, P1.m Habbanim ${ }^{H}$ or Habbanin, Pl.f. Habbányet) lived in the Jewish Quarter, which was called Hâft elYahüd. ${ }^{2}$ Their neighbourhood lay on a mountainside on which the Sultan's fortress (elMișan $\left.{ }^{\varsigma} a^{3}\right)$ was built. The Moslems however resided in a neighbourhood which topographically lay lower down the slope than the Jewish Quarter, which generally caused resentment towards the Jews.

Nowadays most of the Jews from Habbān live in Moshav Baréket in Israel in the vicinity of Ben-Gurion Airport. A few live in Kfar Shalém near Tel Aviv. The clustering of the majority of the community together still today helps them maintain their tradition.

The Jews of Habbān were divided into several clans, which still today are preserved in Israel; every person is deeply conscious as to the clan he or she belongs to. Each clan has its own standing and characteristics. The most eminent are the $M a^{\varsigma} t \bar{u} f$, Híllel, Šammakh (ঙ̌ammax), and Gahlān. ${ }^{4}$

I conducted my fieldwork in Moshav Baréket in 2013. ${ }^{5}$ This article is based on a recording I made on 22 December 2013 in the village with Mrs. Tova Hillel, born in 1945 in Habbān. Al-

\footnotetext{
${ }^{1}$ For more details see YoSEF SHA ${ }^{\mathrm{IS}} \mathrm{AR}$, 'Yehudéy Hatsarmávet: rešít hityašvút ha-Yehudím be- Ḥatsarmávet' [=The Jews of Ḥaḍramawt: The beginning of the Jewish settlement in Hadramawt]. In Tehuda 16, 1996 pp. 2326. See also $\mathrm{S}^{\complement} \mathrm{A} D Y A$ BEN YITSHAK MA $\mathrm{MATU}^{\complement} \overline{\mathrm{T}}$, Yahadút Habbān (Hatsarmávet) ba-Dorót ha-'2Aharoním [The Jews of Habbān (Hadramawt) in recent centuries]. Baréket: The Author, 1987), p.1.

${ }^{2} \mathrm{~S}^{\varsigma}$ ĀDYA BEN YITSHAK MA ${ }^{\varsigma} T ⿱ \mathrm{~T} \mathrm{~F} F$, ibid., pp. 9, 18-24.

${ }^{3}$ Ibid., p. 20.

${ }^{4}$ A family clan is called hil, apparently from the Arabic word ${ }^{3} a h l$ [=family]. There is also hil `́dani. Ibid., p. 11-12.

${ }^{5}$ I would like to express my thanks to Mr. Evyatár Sa' ${ }^{\text {'s }}$ id for helping me during my fieldwork.
} 
so in 2013 I held several interviews at Baréket, where I also attended marriage ceremonies. This linguistic informant participates regularly in marriage ceremonies in Baréket as a singer, and one of the last original authorities in all the details of this ritual. This community still upholds its folklore and customs very strictly, as most Jews of the village in Israel remain deeply religious. Ceremonies are held in the synagogue or in a hall at the village centre. The community is intensely aware of its exceptional tradition: there is a museum of their folklore in the village; the marriage ceremonies especially are still fully adhered to, as are other ceremonies that fill community life.

\section{Some important phonological remarks on the dialect}

The dialect of the Jews of Habbān renders several consonantal shifts from Classical Arabic. Ancient ${ }^{*} q$ shifts to $g,{ }^{6}$ as is normal in Bedouin tribal dialects. ${ }^{*}$ has an allophone which sounds like $g^{y}$, hence differs from $q$ which turns into $g$. The ${ }^{s}$ is very pharyngeal. ${ }^{7}$ Consonants $t$ and $s$ are emphatic in their articulation, but not surprisingly are not greatly velarized. In this dialect we find the suffix $-k$ in feminine personal pronouns tu $\check{s}$, e.g. 'abūš [=your father] and 'alǐs [=on you]. All interdentals are preserved. ${ }^{8}$ These consonantal features represent a highly conservative dialect.

Long vowels tend to be shortened, especially if they consist of only one syllable, as is the case with the particle $y \bar{a}$ [O!] which is often shortened to $y a$.

Accentuation is unique and tends to be implemented as in some Yemeni dialects, thus is not always on the last long vowel. An example is *niswän, which is implemented as níswa $(\sim \bar{a}) n[=$ women].

\section{Marriage Folklore}

The marriage customs of the Habbāni Jews differ entirely from those of other Jewish communities in Yemen. The richness of the traditional musical and oral repertoire and variety is remarkable. In Habbān itself the marriage ceremonies were many - about twenty in number, and went on for several weeks before the marriage itself: elxitbe (asking the parents for their daughter's hand); elqali (a bean-roasting ceremony at the

\footnotetext{
${ }^{6}$ Compare Peter Behnstedt, Die nordjemenitischen Dialekte (Teil 1: Atlas) (Wiesbaden: Dr. Ludwig Reichert, 1985), p. 41, Karte 1.

${ }^{7}$ See more in WERNER DIEM, Skizzen yemenitischen Dialekte (Beirut und Wiesbaden: In Kommission bei Franz Steiner Verlag, 1973), p. 9.

${ }^{8}$ Compare Peter Behnstedt, ibid., p. 44-45, Karte 5.
} 
bride's house, and again at the groom's ( $\left.\operatorname{har} \bar{\imath} w^{9}\right)$, as refreshments before the marriage ceremony); elmadd (display of the dowry items which the groom gives the bride); ěšsidux (שידוך , namely sprinkling oil on the bride's head); shẹeq ețtīb (grinding a mixture of perfumes); sabt ilkullän (trickling oil and scattering dust on the groom's head); hațab (wood chopping); laylet elgṣüd (a night dedicated to liturgy singing); hiddi (preparation of special footwear for the groom); laylet elleile (applying henna to the groom's feet and hands); dagg elhenne (grinding henna); henne (applying henna very artistically to the bride's hands and feet); giddušinn ${ }^{10}$ (קידושין, the wedding ceremony itself); șibeh ('seven blessings'); šabbāt Sos-'Asīs (Aliyah laTorah of the groom); rudiyyeh (the first visit of the bride to her parents' house after the wedding); rhās (dismantling the bride's braids); gahwet essukar (drinking coffee with sugar) and xidded $^{11}$ (a sophisticated braiding ceremony ${ }^{12}$ ). Today only twelve of these ceremonies are maintained; eight have been abandoned and two entirely changed. ${ }^{13}$

Most of the women's marriage songs ${ }^{14}$ are not written, so I had to transcribe some of them, which appear here in the appendix. There is an element of improvisation in the songs I recorded, sung by Tova Hillel. The songs during the marriage ceremony are accompanied by various kinds of dance. ${ }^{15}$

9 Compare with the same meaning Peter BeHnstedT, Glossar der Jemenitischen Dialektwörter in Eduard Glasers Tagebüchern (II, III, VI, VII, VIII, X) (Wien: Verlag der österreichischen Akademie der Wissenschaften, 1993), p. 56.

${ }^{10}$ Compare the root קדש in Moshe PiamentA, Dictionary of PostClassical Yemeni Arabic. V.2 (Leiden, New York, København, Köln: E.J. Brill, 1991), p. 389.

${ }^{11}$ See Moshe Piamenta, Dictionary of Post-Classical Yemeni Arabic. V.1 (Leiden, New York, København, Köln: E.J. Brill, 1991), p. 121: 'Plaiting of Jewish Habbāni bride's hair when returning from ritual bath'.

12 Compare JOSEPH CHETRIT, ha-Hatuná ha-Yehudit ha-Masortí beMaróko [=The traditional Jewish wedding in Morocco] (Haifa: University of Haifa, 2003), p. 535. The tying of a ribbon to the bride's hair among the Jews of Morocco is called rbot äzallum.

13 See more in YAEL SHAY, 'Shirá u-mahól ba-ḥatuná be-ḳérev nešót Habbān' [=Wedding songs and dance among the women of Habbān]. in Tehuda, 15, 1996, pp. 54-57.

${ }^{14}$ On Women's songs in the Jewish communities of Yemen see also HAIM SA'ADON (editor), Teymān [=Yemen]. Jerusalem: Ben-Zvi Institute, 2002 .

15 Tova Hillel was born in Habbān in 1945. The recording was conducted at her home on 22 December 2013 in Bareket. 


\section{The recorded songs}

A bahâlīl song: This is regarded as an opening song, recalling for the groom Jacob's marriage to Leah instead of Rachel. ${ }^{16}$ This song cautions the groom to watch out for any trickery, as played on Jacob. The song begins with an allusion to the name Leah through the Arabic 'illa [literally: = except] and ll $\bar{a}$ [= God]: 'illā ya-sma ll $\bar{a}$ wa hă $u r\{1\}$ [= In the name of God, be careful]. This type of song seems archaic, since it combines Hebrew words and tradition with hints at Arabic words. The two first phrases were sung by the professional singer (Tova Hillel) and the women taking part in the braiding ceremony answered her, as if in a so-called 'echo dialogue'. Here I noticed some room for improvisation, for example, inserting the particle wi, which can be understood as a warning, e.g. 'illa wi ya-sma ll $\bar{a}$ wa hă 'ur. These four verses also serve as a blessing on the bride for a good life as she leaves her parents' house for her new home. Especially notable is the fourth verse: we $g^{y} a^{s} l i \bar{s}$ dūb mug $g^{y} \bar{u} r$ [So you will be all the time honourable]. The rhyming pattern is ABAA.

The bahầīl is followed by the song yā lèlt errahmān [O night of the Merciful]. This song tells of the astrologically happy, blessed hour of the wedding ( harāwa ${ }^{17}$ ), represented by the timing of the appearance of the star (Classical Arabic سعد (18), formally Beta Aquarii, a double star in the constellation Aquarius, but here denoting a fluid and undefined time of good fortune. A pun is found, based on the root $\sqrt{S}_{s^{-}}{ }^{-} d$ [ $[=$ to be happy]. This song describes the entry of the groom. Sometimes improvisations show up in the song, such as we l'anbar [=and the amber] inserted in the fifth line: we-lmēzke we l'anbar yinfah [And the perfumes and amber spread]. This song is a synaesthesia of several senses: sight [of the green plants] and smell [of the perfumes $m \bar{e} z k \bar{e}$ and resin $b^{\varsigma} \bar{u} d$ ]. The rhyming pattern here is $\mathrm{ABCBCB}$.

\footnotetext{
${ }^{16}$ In a wedding song from the Jewish community in Baghdad, Iraq, there is also a reference to Jacob: 'baššig $u$ Ya $a^{\varsigma} q u \bar{b}$ bilela' [=Inform Jacob on the night]. See Y. AvishUR, ha-hatuná ha-Yehudit be-Bagdād u-vnotéha [=The Jewish wedding in Baghdad and its vicinity] (Haifa: University of Haifa, 1990), II, p.87, and also ibid., p. 95: Ya $a^{\varsigma} q \bar{u} b$ ya $\bar{a}^{\varsigma} e \bar{n} i$; compare also ibid., pp. 99, $108(23.3)$.

${ }^{17}$ The groom is called harīw and the bride ' $a r u \bar{u} s$.

${ }^{18}$ Compare Ali Ahmad Hussein, The Rhetorical Fabric of the Traditional Arabic Qașida in its Formative Stages. (Wiesbaden: Deutsche Morgenländische Gesellschaft, Harrassowitz Verlag, 2015), p. 141: 'I met by her the $s a^{\varsigma} d$ as-su'u $d$. At other times / I become displeased once I abandon [my] water courses'.
} 
The bahälil and the subsequent entry of the groom are followed by a second type of song, which accompanies the last stages of the henna spreading ceremony. Its rhythm is slower and it is accompanied by drumming and the zafifäh circledance. $^{19}$

This latter type of songs is quite unusual since it mentions the most important Habbanni clans or families. In the song sung by my informant three clans are named: the $M a^{s} t \bar{u} f$, Š́mmax (Shammakh), and Gahlān. Each is described differently and in a different rhyming pattern. The $M a^{\uparrow} t \bar{u} f$ family is presented in reference to the Habbāni fortress ((elMișan $\left.{ }^{\varsigma} a\right)$ which is a parallel image to the portrayal of the bride. The fortress is stunning as is the bride - since it contains vast halls, chandeliers and priceless swords. It denotes the clan's economic strength.

The Šámmax (Šammakh) family is presented through not only a depiction of the bride but also of her father. ${ }^{20}$ Rather than a lavish lifestyle, this song addresses religion, where a local ceremony of slaughtering a chicken over the bride's head is described as an atonement (Kapparōt). This means that this clan is religiously observant and performs Jewish religious customs meticulously.

The third song of the second type is dedicated to the Gahlān clan, portrayed through images from nature: water [la-yäkarrá ${ }^{\varsigma}$ men galtš Oh stored water of a water-reservoir!] and honey ['asal safiyy and gibh gawiyy=pure honey and fine hive], and there are hints at a life of indulgence through the attribute alhaliyy [spoiled] applied to the bride of this family.

A third type of songs, sung by my informant, comes after the bahālīl. These too have a slow rhythm, accompanied by the zafna-dance. ${ }^{21}$ Sometimes the women clap their hands, although the rhythm tends to vary. This song is called we- $\underline{d} a-$ llayla sa $^{\varsigma}$ ida [O happy night!]. The informant noted that this song is accompanied by body movements rendered by the verb $\sqrt{n}_{n}{ }^{\varsigma}-\check{s}$ (Sing. $\operatorname{tin}^{\varsigma} a \check{s}^{2}$ pl. yin ${ }^{\varsigma} a \check{s} u$ ). The dance itself is offered min hazzit gubāli [to whom may dance in front of me]. The third song is dedicated to the bride, beginning with encouraging phrases meant to turn the gloomy mood into a joyful wedding atmosphere: we-da-llayla 'azamna nhizz ilga'ed liswad [Tonight we are determined to dispel the doleful air]. The bride is

\footnotetext{
${ }^{19}$ See more in YAEL SHAY, ibid., p. 56.

${ }^{20}$ Compare Y. AvisHUR, ha-hatuná ha-Yehudit be-Bagdād u-vnotéha [=The Jewish wedding in Baghdad and its vicinity] (Haifa: University of Haifa, 1990), I, 109: 'בת אלמלוך וכ'וואלכי שג'עאלי']=You are the daughter of kings and your maternal uncles are brave men].

${ }^{21}$ YAEL SHAY, ibid., p. 56-57.
} 
described as beautiful with her diamonds and jewellery; she smells as good as fresh basil, and she is well rounded. The description builds up by means of rhetorical questions in a dialogue between the singing women and the bride. The women ask minnēn 'inti hașīnä? min ilsamn ilmṣaffa w kubr l'aginnä? [Where do you get to be so pretty from? Where to you get to be so pretty from? Is it from the pure butter? Or is it from the large dough?]; the bride answers as if she has not heard their questions asked in public. She speaks of the husband she is going to marry, as if he is the actual cause of her beauty min zōg iddálla $\bar{a}^{\varsigma}$ $m a-y^{\varphi} u d n i$ bi-ttabinán ${ }^{22}$ [Or perhaps will it be the spoiling husband?] The third songs ends with the groom's appeal, in which he gives sexual intimations referring to the semantic meaning of 'lending', which at this point are acceptable as he is going to marry the bride subayya sillifini $w$-'ana hibb ilmsillif [Oh girl, please lend me as I love this money-lender!]. He also hints to his future bride about his excellent financial situation bèti mtarráf 'ala bēti taranga $w$ rummāna t'innif [my house is wide $\{=$ big $\}$ And...I have near my house a citron tree and a pomegranate, both loaded with fruits?]. ${ }^{23}$

The fourth type of songs has a characteristic quick rhythm, accompanied by raqsa-dancing ${ }^{24}$ and drum beating. This is the time of the procession (siyyar). A wide range of improvisations tell of God versus Satan, each respectively seeking to draw/lure the bride onto the right/wrong path. The bride is admonished to go in the good path of God and the Holy (Jewish) Bible, to behave well tigs $a y^{25} w$ khaylä [you have to behave yourself] with the groom, and to eschew rumour-mongering, which is characteristic of women and demons.

My recordings covered a fifth type of wedding songs, titled yegūl 'Abü-Sālem [Abu-Sālem says:]. This type refers to three men: Abu-Sālem, Abu-Sādya, and Abu-īazāl. One of the first two is apparently the father of the groom [Abu-Sālem]; his companion is perhaps a rabbi [Abu-Sādya]. Abu-ïazāl is the name given to the father of the bride [literally = father of the deer] since this type of song has an image of the bride as a

${ }^{22}$ See Dictionary of Post-Classical Yemeni Arabic. V.2 (Leiden, New York, København, Köln: E.J. Brill, 1991), p. 300: 'طبينه pl. طبائن = rival wife, a wife other than the first of dual or plural marriage'.

${ }^{23}$ Compare Y. RAtZABY, Mizimrat Temán: Yemenite Folksongs (Tel Aviv: Hakibbutz Hameuchad Publishing House, 1981), p. 53: ' עץ פרי הדר 'בגני [=there is a citrus tree in my garden].

${ }^{24}$ YAEL SHAY, ibid., pp. 56-57.

${ }^{25}<\sqrt{ } * w-q-{ }^{\varsigma} I$ : see HAMDI A. QAFISHEH, NTC's Yemeni Arabic-English Dictionary (Lincolnwood, Chicago: NTC Publishing Group, 1999), p. 632: 'to be'. 
deer. It has a long neck, which is a symbol of beauty $w^{\complement} u n g u h a$ šíbreyn $^{26} w^{2}$ 'arba'a banāyn -'ala đỉba ${ }^{27}$ zayyad b-gāma [And her neck is in the length of twenty centimetres and two thumbs]. The groom swears that he will be faithful to his bride and will never love another woman dowba 'alayy ma-hib mifla had $a$ [Atonement on me, I will never love anybody except her]. A description follows telling why the groom fell in love with his bride, and one reason is her hair, which is combed to perfection. This hints at the hair-braiding ceremony, which is of great importance for the Jews of Habbān.

A very interesting description of the bride's outer appearance in this type of song symbolizes a woman's exemplary beauty. The picture starts with her beauty-spot ( $\check{s} \bar{a} m a)$ and her eyes ( $\left.{ }^{\varsigma} y \bar{u} n\right)$, then step by step descends to describe other bodily parts: her nose $\left(x u s ̌ m{ }^{28}\right)$, her lips $\left(\right.$ míbșima $\left.^{29}\right)$, her neck $\left({ }^{(} u ́ n u g{ }^{30}\right)$, her chest (șadr), and finally her belly (buṭ).

Nothing below this part is portrayed for reasons of modesty. ${ }^{31}$ The descriptions in this song seem very archaic and bellicose in their type, akin to similes in pre-Islamic poetry for women. The bride does not leave the house of her future husband except on account of the exigencies of war. Even the description of the chest, namely the breasts, is markedly crude: the ideal is a huge breast, 'as wide as a square'. It reminds us of pre- and early Islamic poetry of men who fell in platonic love with women. But here the similes and depictions are blunt and too sensual for a description of a bride, who is going to be a wife of one man. Even the picture of the bride's belly is somewhat coarse, apt for a vision of an overweight woman whose plump belly is described as 'prime silver silk...for bonnets'.

${ }^{26}$ See PETER BENSTEDT, Glossar der Jemenitischen Dialektwörter in Eduard Glasers Tagebüchern, p. 112: 'Spanne'.

${ }^{27}$ Compare JefFrey DeBOO, Jemenitisches Wörterbuch (Wiesbaden: Otto Harrassowitz, 1989), p. 45: dabi/đuba, đuban=gazelle.

${ }^{28} \mathrm{~S}^{\varsigma} \bar{A} \mathrm{DY}$ A BEN YITSHAK MA MṬūF, Milón 'Ivrí-'Arví be-Dialékt Habbāni [=A Hebrew-Arabic dictionary in the dialect of Habbān] (Baréket: The Author, 2007), p.8.

${ }^{29}$ Compare Moshe Piamenta, Dictionary of Post-Classical Yemeni Arabic. V.1, p. 33: 'mouth'.

عنق< 30

${ }^{31}$ Compare the poetry of Šanfarā for modesty criteria: ولقد أعجبني لا سقوطا قناعُها [=I liked that her veil never falls down]. AHMAD MuḤAMMAD `ABĪD,

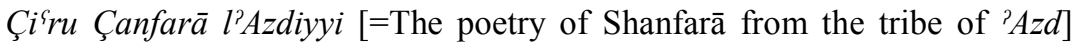
(Abu Dhabi: alMağma ${ }^{\uparrow}$ at-Taqafiyyu, 2000), p.1. 


\section{Conclusion}

The Jews of Habbān lived as a remote and isolated community in eastern Yemen - a geographical location that contributed to making its tradition unique. Thematically its wedding songs share a common basis with those of Jews in other parts of Yemen, and also of other Jewish communities, for example, in Iraq and Morocco. The Habbāni Jews were renowned as bodyguards. The songs reflect the bride's feisty spirit: she does not leave her house for reasons of modesty - but if she breaks the rule it is only because of wars.

As mentioned earlier, the outward appearance of the Habbān Jews made them exceptional among the Jews of Yemen. Their long hair and half-nakedness gave them an archaic look. This echoes the pre-Islamic ambience. Likewise the bride's physical description - from her upper bodily features such as her hair, then down to her belly. This same motif is found in the preIslamic poetry of an-Nābiga. Common Jewish motifs are the references to Jacob and Leah and the portrayals of the groom and bride. However, what makes these songs unique is the account of the Habbān landscape with its fortress, in reference to the various clans of this Jewish community.

The dialect of the songs is archaic in its vocabulary and it associates with the dialects of eastern Yemen and Hadramawt. This was the sole Jewish community in this remote corner of the world. The fact that most of the Habbān Jews have lived in the same village since their arrival in Israel, their religiousness, and their high motivation to preserve their customs, undoubtedly help preserve their tradition and dialect, unlike dialects of Jews from other Arabic-speaking countries, which are threatened with extinction. However, the geographical distance from their original village in eastern Yemen delays dialectal obsolescence only temporarily. Most probably, also inevitable is the disappearance of the subtleties of culture that only in the vast deserts of Hadramawt could have been preserved for centuries as an oral tradition. 


\section{Appendix : The Wedding Songs Xidded}

I. 'bahälīl'

'illā (wi) ya-sma !̣la wa hă đur ${ }^{32}$ In the name of God, be careful

\begin{tabular}{|c|c|}
\hline 'alī̌s ya-bint el' $h b \bar{u} r^{33}$ & $\begin{array}{l}\text { on you, you too, oh daughter of } \\
\text { rabbis }\end{array}$ \\
\hline wa-min 'yūn ilmanāḥ̂is & $\begin{array}{l}\text { Beware of the eyes of the envi- } \\
\text { ous }\end{array}$ \\
\hline we $g^{y} a^{\varsigma} l i s ̌ s \bar{u} b$ mug ${ }^{y} b \bar{u} r$ & $\begin{array}{l}\text { So you will be all the time hon- } \\
\text { ourable }\end{array}$ \\
\hline
\end{tabular}

\begin{tabular}{|c|c|}
\hline 'ya-lēlt erraḥmān' & $\mathrm{O}$, the night of the Merciful \\
\hline ya-lēlt errḥmān & O the night of the Merciful \\
\hline$d x a l s e^{\varsigma} d$ is ${ }^{\varsigma} \bar{u} d$ & The Sadalsuud-star entered \\
\hline fi ha-lx'ēe mayyah ${ }^{34}$ & All the plants are swaying \\
\hline we rriyāha tnūd & And the pleasant smells scattered \\
\hline we-lmēzke yinfah & And the perfumes spread \\
\hline we lksā daxxan $b^{\varsigma} \bar{u} d$ & $\begin{array}{l}\text { The [groom's] clothes }{ }^{35} \text { smell of } \\
\text { resin }\end{array}$ \\
\hline
\end{tabular}

\begin{tabular}{|c|c|}
\hline II. ya-benti Ben-Me'tūf (x2) & O daughter of Ma'țūf-Family \\
\hline ya-harf elhrūf & O daughter of Ma'țūf-Family \\
\hline 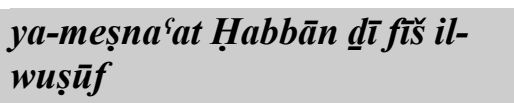 & O ineffable fortress of Habbān \\
\hline fǐs elganābi we ttarāki we-ș̣yūf & $\begin{array}{l}\text { In you there are halls, chande- } \\
\text { liers and swords }\end{array}$ \\
\hline ya-benti Ben Šámmax (x2) & $\begin{array}{l}\text { O daughter of Shammakh- } \\
\text { Family }\end{array}$ \\
\hline 'abūš ilmirba'i & Your father is a great man \\
\hline
\end{tabular}

${ }^{32}$ Compare S`ĀDYA BEN YITSHAK MA MṬ̂̄F, Milón 'Ivrí-`Arví be-Dialékt Habbāni, p. 137.

${ }^{33}$ Compare Moshe Piamenta, Dictionary of Post-Classical Yemeni Arabic. V.1, p. 81: 'hibr pl. -ān scholar, scholar of the law'.

${ }^{34}$ Compare Moshe Piamenta, Dictionary of Post-Classical Yemeni Arabic. V.2 (Leiden, New York, København, Köln: E.J. Brill, 1991), p. 475: 'ميح II-I to pass by land; V to go and come'.

35 On the groom's attire in Jewish communities in Yemen see EsTER MuchawsKY-SCHNAPPER, Yehudéy Teymán [=The Jews of Yemen] (Jerusalem: Israel Museum, 1999), pp. 94-95. 


\begin{tabular}{|c|c|}
\hline gídliš țalāta 'ayyām & Since the last three days \\
\hline biga $a^{\varsigma}$ diš tinșa $a^{\zeta}$ & He lets you shine \\
\hline bahúwwa'iš bā-simm & He makes a ritual on your behalf \\
\hline 'asa la-tifzasi & $\begin{array}{l}\text { Hopefully you will not be afraid } \\
\text { of it }\end{array}$ \\
\hline ya-benti Ben-Gahlān (x2) & O daughter of Gahlān-Family \\
\hline ya-bint elhaliyy & O a spoiled child! \\
\hline la-ya-`asal șafiyy & O a pure honey! \\
\hline min lgibh elgawiyy & From a fine hive \\
\hline la-yäkarrás men galť̌s & $\begin{array}{l}\text { O stored water of a water- } \\
\text { reservoir! }\end{array}$ \\
\hline III. we-da-llayla sa'îda & O happy night! \\
\hline w zāad elwagt sā $\bar{a}^{\zeta} i d$ & And the time became happier \\
\hline we-da-llayla 'azamna & This night we are determined \\
\hline nhizz ilga ${ }^{\varsigma} e d$ liswad & $\begin{array}{l}\text { To revoke the depressive atmos- } \\
\text { phere }\end{array}$ \\
\hline \multicolumn{2}{|l|}{$\left(\operatorname{yin}^{\varsigma} a \check{s ̆}^{36}\right)$} \\
\hline lak ya-ḡāli $\lg ^{Y} a d d$ & To you, O dear Grandfather \\
\hline wa-ya-hayya-!!la & Welcome all \\
\hline min hazzit gubāli & $\begin{array}{l}\text { To whom may dance in front of } \\
\text { me }\end{array}$ \\
\hline \multicolumn{2}{|l|}{$\left(\operatorname{tin}^{\varsigma} a{ }^{5}\right)$} \\
\hline baddít bi-l'sng líblag & She revealed with her white neck \\
\hline w fïha 'arba' ${ }^{\varsigma}$ a marāri & Which has four gems \\
\hline wa-ya-hayya-!!la & Oh, welcome all \\
\hline$l^{\varsigma} u n g \underline{d} \bar{i}$ šall lmarāri & The neck that took all the gems \\
\hline 'Al!á ya-la'ba & What a lovely bride is she! \\
\hline gālet 'ummịiš & Your mother prayed: \\
\hline 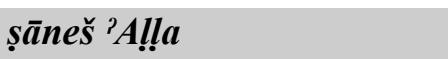 & 'May God keep you! \\
\hline we tifdiš ilganam w ilbagar & $\begin{array}{l}\text { And may he redeem you with } \\
\text { sheep and cattle }\end{array}$ \\
\hline we lhāres 'A!l!a & And may he guard you!' \\
\hline
\end{tabular}

\footnotetext{
${ }^{36}$ The dancer stands in front of the bride; she tries to make sure not to turn her back on the bride or the wedding guests. She turns her head and twists her braids before the bride and then another dancer stands up and dances in front of the bride, while the first dancer returns to her place. See more in YAEL SHAY, op. cit., p. 56.
} 


\begin{tabular}{|c|c|}
\hline 'Al!̣á ya-la'ba & What a lovely bride is she! \\
\hline ya-šgūrr kulla hamāhim & Oh fragrant basil full of sprouts! \\
\hline w min šámmeš šgurr & $\begin{array}{l}\text { Who smells you [knows that you } \\
\text { are] a fragrant basil }\end{array}$ \\
\hline ya-șabiyy síllim darāhim & Oh girl, full of silver coins! \\
\hline șubayyä xabbrīni & Tell me, oh girl! \\
\hline minnēn 'inti ḥașīnä & $\begin{array}{l}\text { Where do you get to be so pretty } \\
\text { from? }\end{array}$ \\
\hline min elsamn ilmṣaffa & Is it from the pure butter? \\
\hline w kubr l'agīnä & Or is it from the large dough? \\
\hline minnēn 'inti ḥașīnä & $\begin{array}{l}\text { Where do you get to be so pretty } \\
\text { from? }\end{array}$ \\
\hline min elsamn ilmṣaffa & Is it from the pure butter? \\
\hline w kubr l'agīna & Or is it from the large dough? \\
\hline $\min e z z \bar{o} g$ lddállāa & $\begin{array}{l}\text { Or perhaps will it be the spoiling } \\
\text { husband? }\end{array}$ \\
\hline ma-y'udni bi-ț̣abīná & $\begin{array}{l}\text { That never threatens to take a } \\
\text { second wife! }\end{array}$ \\
\hline șubayya síllifīni & Oh girl, please lend me \\
\hline w-'ana hibb ilmsillif & As I love this money-lender! \\
\hline wa la-ma-ta'rifini & Don't you know me? - \\
\hline bēti mtarráf & My house is wide, \\
\hline $\begin{array}{l}\text { 'ala bēti taranga w rummāna } \\
\text { t'innif }\end{array}$ & $\begin{array}{l}\text { And that I have near my house a } \\
\text { citron tree and a pomegranate, } \\
\text { both loaded with fruits?! }\end{array}$ \\
\hline
\end{tabular}

\begin{tabular}{|c|c|}
\hline IV. Zaffe: Síyyar & Marriage/Procession \\
\hline 'ala séyri, 'ala séyri & $\begin{array}{l}\text { On the procession, on the proces- } \\
\text { sion }\end{array}$ \\
\hline 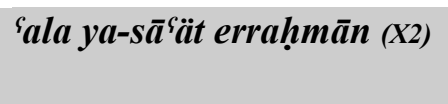 & $\begin{array}{l}\text { On the procession, on the proces- } \\
\text { sion }\end{array}$ \\
\hline 'Al!la yexzak ya-šáytạn & $\begin{array}{l}\text { May God humiliate you, O Sa- } \\
\text { tan! }\end{array}$ \\
\hline 'allā tedxuli l-'áwtāan & $\begin{array}{l}\text { Please do not enter (O bride) his } \\
\text { territories! }\end{array}$ \\
\hline fi xēer ya-binti & There is goodness, $\mathrm{O}$ girl \\
\hline wadda'tēš erRahmā̄n & May God accompany you, \\
\hline binti bi-g ${ }^{Y} \bar{a} h{ }^{\top} A ! l l \bar{a}$ & $\begin{array}{l}\text { my daughter with the glory of } \\
\text { God }\end{array}$ \\
\hline w bi-g ${ }^{y} \bar{a} h$ essēefer ${ }^{H}$ & and the glory of the Bible! \\
\hline 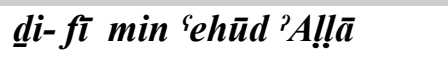 & These are the promises of God \\
\hline
\end{tabular}




\begin{tabular}{|c|c|}
\hline 'A!!̣a bașĭ̌s ya-bintiy & $\begin{array}{l}\text { I recommend you this advice, } \\
\text { O my daughter, in the name of } \\
\text { God! }\end{array}$ \\
\hline min tig'ay w khaylä & that you have to behave yourself \\
\hline 'A!!̣ā bașĭ̌̌ ya-bintiy & $\begin{array}{l}\text { I recommend you this advice, } \mathrm{O} \\
\text { my daughter, in the name of } \\
\text { God! }\end{array}$ \\
\hline min meg'ad enníswan & $\begin{array}{l}\text { Stay away from women -gossip- } \\
\text { sessions }\end{array}$ \\
\hline ysayneš w-yilhayneš & $\begin{array}{l}\text { That will waste your time and } \\
\text { distract your mind }\end{array}$ \\
\hline w yilgu fi-gulayybiš g $g^{y}$ ann & $\begin{array}{l}\text { Lest they will bring into your } \\
\text { heart demons! }\end{array}$ \\
\hline V. yegūl 'Abū-Sālem & Abu-Sālem says \\
\hline yegūl 'Abū-Sālem & Abu-Sālem says: \\
\hline$w-{ }^{2} A b \bar{u}-S^{\varsigma} a d i y \ddot{a}$ & And also Abu-S؟ādya \\
\hline yegūl 'Abū-Sālem & Abu-Sālem says \\
\hline$w-{ }^{2} A b \bar{u}-S^{\varsigma} a d i y \ddot{a}$ & And also Abu-S`ādya \\
\hline 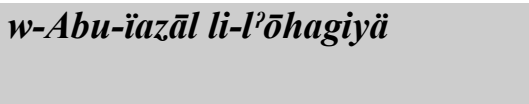 & $\begin{array}{l}\text { And also Abu-Ghazāl to those } \\
\text { who fell in love: }\end{array}$ \\
\hline dowba 'alayy ma-hibb & $\begin{array}{l}\text { Atonement on me, I will never } \\
\text { love }\end{array}$ \\
\hline mițla hada & Anybody except her \\
\hline ma-hábbeta sámmet fu'ādi & $\begin{array}{l}\text { The moment I fell in love with } \\
\text { her - she poisoned my heart }\end{array}$ \\
\hline gatța a lgínwada & She broke my shoulders \\
\hline w-ittsargadat 'indha šawādi & And warriors kneeled before her \\
\hline $\begin{array}{l}\text { w xaddaha múxđub }{ }^{37} \text { mīlan be- } \\
\text { mīl }\end{array}$ & $\begin{array}{l}\text { Her hair-tail is combed meticu- } \\
\text { lously }\end{array}$ \\
\hline $\begin{array}{l}\text { mil ed }{ }^{d} \underline{d a h a b} \text { namnam } w \text { šāma } \\
\left(y \bar{a} d \bar{a}{ }^{38}\right)\end{array}$ & $\begin{array}{l}\text { Full with shining gold and she } \\
\text { has a beauty-spot }\end{array}$ \\
\hline$w^{\varsigma}$ yūnaha ya-nār tišs'al s'eyl & And her eyes are blazing fire \\
\hline min hírritha ti'har șmāma & Their heat causes chills. \\
\hline
\end{tabular}

${ }^{37}$ Compare Moshe Piamenta, Dictionary of Post-Classical Yemeni Arabic. V.1, p. 130: 'to stir up (a liquid); to mix'. See also PETER BEHNSTEDT, Die nordjemenitischen Dialekte (Teil 1: Atlas) (Wiesbaden: Dr. Ludwig Reichert, 1985), p. 329: 'umrühren; beat up'.

${ }^{38}$ A word that appears in the songs and whose meaning is not certain but only rhetorical. 


\begin{tabular}{|c|c|}
\hline w xúšmaha ya-seyf yuṣgul șagīl & And her nose carved neatly \\
\hline ma-xārgy a 'illā li-hirāāba & She goes out only towards wars. \\
\hline $\begin{array}{l}\text { we míbșima barig barag min } \\
\text { naháyl }\end{array}$ & Her lips have a shine like hives \\
\hline tgūl d् da-barig thāma! & $\begin{array}{l}\text { You could say - it is like a light- } \\
\text { ning of Tihāma! }\end{array}$ \\
\hline $\begin{array}{l}\text { w'unguha šíbreyn } w^{`} \text { arba'a } \\
\text { banāyn }\end{array}$ & $\begin{array}{l}\text { And her neck is in the length of } \\
\text { twenty centimetres and two } \\
\text { thumbs }\end{array}$ \\
\hline 'ala 'íba zayyad b-gāma & $\begin{array}{l}\text { Which is longer than the length } \\
\text { of a deer's (neck) }\end{array}$ \\
\hline w șádraha mīdän li-lmūla ŝ̀n & $\begin{array}{l}\text { And her breast is as wide as a } \\
\text { square for those who crave }\end{array}$ \\
\hline $\begin{array}{l}\text { w kam min wullāa garred } \\
\text { husșāna! }\end{array}$ & $\begin{array}{l}\text { How many cravers dragged her } \\
\text { horses! }\end{array}$ \\
\hline w búṭaha șūṣi șawānef ḥarīr & $\begin{array}{l}\text { And her belly is like prime silver } \\
\text { silk }\end{array}$ \\
\hline ma-xargya'aha 'illa li-l'imāma! & which is used only for Bonnets! \\
\hline
\end{tabular}

${ }^{39}$ Compare Moshe Piamenta, Dictionary of Post-Classical Yemeni Arabic. V.1, p. 54 'low plain'. 


\section{Bibliography}

'ABīD, AHMad MuHammad, $\check{S i}^{i} r u$ Šanfarā l'Azdiyyi. [= The poetry of Shanfarā from the tribe of $\left.{ }^{2} \mathrm{Azd}\right]$. Abu Dhabi: alMağma ${ }^{\top}$ u at-Taqafiyyu, 2000.

AVISHUR, YITSHAK, ha-ḥatuná ha-Yehudit be-Bagdād uvnotéha [= The Jewish wedding in Baghdad and its vicinity]. I, II. Haifa: University of Haifa, 1990.

BeHNSTEDT, PETER, Glossar der Jemenitischen Dialektwörter in Eduard Glasers Tagebüchern (II, III, VI, VII, VIII, X). Wien: Verlag der österreichischen Akademie der Wissenschaften, 1993.

ID., Die nordjemenitischen Dialekte (Teil 1: Atlas). Wiesbaden: Dr. Ludwig Reichert, 1985.

ID., Die nordjemenitischen Dialekte (Teil 2: Glossar, AlifDāl). Wiesbaden: Dr. Ludwig Reichert, 1992.

ID., Die nordjemenitischen Dialekte (Teil 2: Glossar, DālGayn). Wiesbaden: Dr. Ludwig Reichert, 1996.

CHETRIT, JosePH, ha-Hatuná ha-Yehudit ha-Masortí beMaróko [= The Traditional Jewish Wedding in Morocco]. Haifa: University of Haifa, 2003.

DeBOO, JefFReY, Jemenitisches Wörterbuch. Wiesbaden: Otto Harrassowitz, 1989.

DIEM, WERNER, Skizzen yemenitischen Dialekte. Beirut und Wiesbaden: In Kommission bei Franz Steiner Verlag, 1973.

Hussein, Ali Ahmad, The Rhetorical Fabric of the Traditional Arabic Qașìda in Its Formative Stages. Wiesbaden: Deutsche Morgenländische Gesellschaft, Harrassowitz Verlag, 2015.

'IBRĀHĪM, MuHammad ABU LFAḌL, Dīwān an-Nabigha alDhubiyān̄̄ . Cairo: Dār al-Ma`ārif, 1977.

MA ${ }^{\complement} T \underline{T} F, \mathrm{~S}^{\complement} \bar{A} \mathrm{DYA}$ BEN YITSHAK, Milón 'Ivri- ${ }^{\varsigma}$ Arví be-Dialékt Habbāni [= A Hebrew-Arabic dictionary in the dialect of Habbān]. Baréket: The Writer, 2007.

ID., Yahadút Habbān (Hatsarmávet) ba-Dorót ha-'2Aharoním [The Jews of Habbān (Hadramawt) in recent centuries]. Baréket: The Author, 1987.

MuchawsKy-SchnapPer, Ester, Yehudéy Teymán [= The Jews of Yemen]. Jerusalem: Israel Museum, 1999.

Piamenta, Moshe, Dictionary of Post-Classical Yemeni Arabic. V.1 and V.2, Leiden, New York, København, Köln: E.J. Brill, 1991.

QAfisheh, HAMDi A., NTC's Yemeni Arabic-English Dictionary. Lincolnwood, Chicago: NTC Publishing Group, 1999. 
Ratzaby, ZeHudA, Yehudéy Teymán [= The Jews of Yemen]. Jerusalem: Israel Museum, 1999.

SA'ADON, HAIM (editor), Teymān [= Yemen]. Jerusalem: Ben-Zvi Institute, 2002.

SHA AR, YoseF, 'Yehudéy Hatsarmávet: rešít hityašvút haYehudím be- Hatsarmávet' [= The Jews of Hadramawt: The beginning of the Jewish settlement in Hadramawt]. In Tehuda 16, 1996 pp. 23-26.

SHAY, YAEL, 'Shirá u-mahól ba-ḥatuná be-kérev nešót Habbān' [= Wedding songs and dance among the women of Habbān]. In Tehuda, 15, 1996, pp. 54-57. 